\title{
Political Alienation: Behavioral Implications of Efficacy and Trust in the 2008 U.S. Presidential Election
}

\author{
Priscilla Southwell \\ Department of Political Science, University of Oregon \\ Eugene, Oregon 97403, USA \\ Tel: 1-541-346-4866 E-mail: psouth@uoregon.edu
}

\author{
Received: February 6, 2012 \\ Accepted: March 7, 2012 Published: June 1, 2012 \\ doi:10.5539/res.v4n2p71 \\ URL: http://dx.doi.org/10.5539/res.v4n2p71
}

\begin{abstract}
This research centers on three dimensions of political alienation - internal efficacy, external efficacy, and political trust. Multivariate analysis of the demographic determinants of political efficacy and trust suggests that females, blacks, and latinos were more like to exhibit feelings of internal and external efficacy, but trust is significantly higher only among the well-educated and strong partisans. We then examined the behavioral implications of these attitudes on voter turnout and candidate preference in the 2008 presidential election. Logit analysis of the 2008-2009 American National Election Study data suggests that internal efficacy increases turnout while external efficacy and trust are insignificant. With regard to candidate preference, those individuals exhibiting internal and external efficacy were more likely to vote for Barack Obama, while trust was insignificant.
\end{abstract}

Keywords: Alienation, Turnout, Obama, Presidential election, Efficacy, Trust

\section{Introduction}

During the late 1960s and early 1970s, Americans became less attached to the two major political parties, more cynical about elected officials and political institutions, and less confident in their own abilities to influence the political system. However, such attitudes have become less prevalent in the last decade, as indicated by Figure 1 . Using three indices of the most common attitudinal measures from the American National Election Study for trust, government responsiveness, and political efficacy (such as "People like me have no say in government"), this figure suggests that Americans have become more trusting and more efficacious in recent years. Although none of these indices has returned to the high level of 1964, each of them has climbed since the early 1990s, despite the drop in 2004.

[Insert Figure I about here]

This research first examines the political attitudes of efficacy and trust in the 2008 election with regard to the demographic determinants of such attitudes. Our expectation is that low levels of efficacy and trust will occur more often among less privileged individuals or those who have experienced discrimination in the past. Yet, we can also imagine that the climate of the 2008 election may have encouraged such Americans to be more optimistic about government. For example, are minorities more likely to feel distrustful of government and feel less powerful to influence the political system? Or did the Obama candidacy and the "Politics of Hope" campaign message help to alleviate such negative assessments (Avery, 2006; Avery, 2009.)

We also address the behavioral consequences of political trust and efficacy on voter turnout and candidate choice. Efficacy has previously been linked to higher levels of voting, as those who are more confident of their ability to influence politics are more likely to vote (Abramson \& Aldrich, 1982; Craig, 1993; Southwell, 1985; Weatherford, 1991, 1992). High levels of trust often evoke loyalty to the system, hence increased participation (Hetherington, 1998, 2005; Rudolph \& Evans, 2005; Teixeira, 1987, 1992; Weaklin \& Borch, 2006). However, distrustful individuals can also be spurred on by their desire "to throw the rascals out" (Citrin, 1974, 1977, 2001).

So, we might expect that the rise in political trust and efficacy in recent years to increase turnout in 2008, but also to rally behind the candidacy of Barack Obama. The assumption is that the mobilization efforts of the 
Democratic Party, primarily directed at blacks, latinos and young persons was effective in both getting such persons to register and vote for the Obama/Biden ticket (Avery, 2006, 2009; Nagourney, 2008)

This effect of growing trust and efficacy, combined with voter mobilization, would represents a sea change from the disillusionment (and lower turnout) of earlier decades. The conduct of the Vietnam War under the Johnson and Nixon Administrations, coupled with the urban unrest that erupted in the late 1960s, certainly affected the general public's assessment of the capabilities and competence of public and party officials (Tolchin, 1998). The slowly evolving revelations of Watergate, with widespread implications for other political figures outside of the Nixon White House, led many Americans to question the impact of the electoral process when large campaign contributors were shown to have influenced major decisions ranging from government contracts to ambassadorial posts. As additional political scandals from Abscam and the Iran-Contra affair to President Clinton's impeachment trial unfolded in subsequent decades, these feelings of alienation continued to grow among the American public. Certainly the war in Iraq and the worsening economy under the Bush administration did little to assuage concerns of Americans, but then Barack Obama emerged as a candidate who could "change" the system. Did his candidacy alter the political landscape such that "outsiders" became more hopeful and participatory?

\section{The Concept of Alienation}

The concept of political alienation refers to a set of attitudes or opinions that reflect a negative view of the political system. Political alienation represents a less-than-positive view of the political world; it indicates displeasure with political leaders and institutions. Robert Lane defined the concept of alienation as "an individual's disapproval of the way political decisions are made" (1962, p. 162). In a similar vein, Franz Neuman describes alienation as a "conscious rejection of the whole political system which expresses itself in apathy" (1957, p. 290).

Political alienation, as Neuman suggests, can include a sense that one is powerless to influence the political system. Such individuals often feel incapable of having any meaningful impact on political events or developments. Although political alienation represents a general disillusionment and disenchantment with the political system, the concept includes a number of different dimensions, some of which may be present in different degrees in an alienated individual.

A major advance in approaching the definitional problems of alienation was the research on the dimensionality of this concept (See Finifter, 1970; and also subsequent works by Clarke \& Acock, 1989; Niemi, Craig, and Mattei, 1991; Weatherford, 1991, 1992.) This type of inquiry breaks down the larger concept of alienation in order to specify the dimensions of alienation by identifying the different ways in which political alienation may be expressed: "internal efficacy," "external efficacy" or government responsiveness, and "trust." Alienation implies the lack of these allegiant set of beliefs, and are also referred to by their more negative counterparts: "powerlessness," "meaninglessness," and "cynicism," respectively.

Internal efficacy reflects the individual's assessment of how much power or influence he or she can have on the course of political events and outcomes. External efficacy, or government responsiveness, represents a more general evaluation of how receptive are political institutions to input from all individuals in society, not simply the individual himself. This dimension refers to beliefs about whether political parties offer meaningful choices among candidates, whether elections provide an effective way for citizens to influence the political system, and whether elected bodies are representative of the general public (Gilmour and Lamb, 1975). Political trust is an evaluation of whether the government is producing policies according to expectations. Politically trustful individuals are generally satisfied with the procedures and products of government (Erikson, Luttbeg, \& Tedin, 1980). We now turn to an assessment of such attitudes in the 2008 election year (Note 1).

\section{Demographic Determinants of Political Alienation}

Table 1 displays the relationship between these three dimensions of alienation and the standard demographic and partisan categories, as three separate multivariate analyses (Note 2). While one might expect that those individuals with lower socioeconomic status, as well as minorities and women, to have lower levels of efficacy and trust, as discussed above, these results suggest otherwise. Although well-educated individuals and strong partisans are the most trusting and efficacious, increasing age is only associated with feelings of external efficacy or government responsiveness. Most noteworthy is the contrast between efficacy and trust for females, latinos, and blacks. Such individuals are more likely to be efficacious, both internally and externally, but no more trusting of government than others. Income shows no significant relationship to such attitudes, and individuals classified as "other race" in the ANES survey show higher levels of internal efficacy only. 
[Insert Table 1 about here]

\section{The Consequences of Political Alienation}

We now turn to the effect of efficacy and trust on subsequent political behavior. The three different dimensions of alienation may combine in different ways, and result in a variety of behaviors. A distrustful individual, who nonetheless feels that voting is an effective way to influence the political system, may be motivated to vote in order to oust the current administration or party in power (Note 3). In contrast, another similarly distrustful individual but who feels inefficacious as well, is likely to stay home on election day. The results of Table 1 also suggest that the high levels of efficacy among females, latinos and blacks may have led them to vote in the 2008 election, and thus to help the candidacy of Barack Obama. Logit estimates for turnout (Model 1) and vote choice (Model 2) are presented in Table 2 (Note 4).

[Insert Table 2 about here]

With regard to voter turnout (Model 1), these results confirm the standard relationship between age, education, income, and partisanship (Note 5). Older, well-educated, wealthier individuals are more likely to vote, along with strong Democrats or Republicans. Race and gender have little or no effect on turnout. Among the set of efficacy and trust variables, the results suggest that only internal efficacy is positively related to voter participation. These findings suggest that attitudes that directly relate to an individual's assessment of his or her own abilities are factors in voting behavior. However, even those individuals who are distrustful of government or feel it is unresponsive can be motivated to vote.

Turning to presidential vote choice (Model 2), the heightened feelings of internal efficacy among females, blacks, and latinos (as shown in Table 1) appears to have made them the strongest supporters of the Obama candidacy. Members of other nonwhite races and the highly educated were also more likely to vote for Obama over McCain. Independents were more likely to back Obama than were strong partisans, suggesting that he had a broad-based appeal. Wealthier individuals were less likely to vote for Obama, as expected. However, the age variable is insignificant. Efficacy is positively related to vote for Obama, while trust remains insignificant as in the turnout model. Those who felt that they could influence politics, and that the government cared about their political views were more likely to support his candidacy.

\section{Summary and Conclusions}

Alienation, as defined by low levels of political efficacy and trust, is not evenly distributed across U.S. society, and these three attitudes also have differing effects on subsequent political behavior. Blacks, latinos, women, and well-educated partisans are the most efficacious. However, only education and partisanship are associates with higher levels of trust. Only internal efficacy is linked to voter turnout, after controlling for the standard demographic determinants of voting. Yet both internal and external efficacy are positively related to a vote for Barack Obama in the 2008 election, suggesting that he was able to appeal to those who were more optimistic about their political influence. Political trust remains an insignificant factor with regard to both turnout and political choice, confirming the recent findings in the social sciences. Despite these mixed results, these findings also confirm the effect of such evaluations on important political actions and behaviors.

\section{References}

Abramson, P., \& Aldrich. (1982). The Decline of Electoral Participation in America. American Political Science Review, 76(3), 502-521.

Atkeson, L. R., McCann, J. A., Rapoport, R. B., \& Stone, W. (1996). Citizens for Perot: Assessing Patterns of Alienation and Activism. In Craig. S. C. (Ed). Broken Contract. Boulder, CO: Westview Press.

Avery, J. M. (2009). Political Mistrust among African Americans and Support for the Political System. Political Research Quarterly, 62(1), 132-145. http://dx.doi.org/10.1177/1065912908316342

Avery, J. M. (2006). The Sources and Consequences of Political Mistrust among African Americans. American Politics Research, 34(5), 655-682. http://dx.doi.org/10.1177/1532673X06286366

Citrin, J. (1974). Comment: The Political Relevance of Cynicism in Government. American Political Science Review, 68(3), 973-988.

Citrin, J. (1977). Political Alienation as a Social Indicator: Attitudes and Actions. Social Indicators Research, 4(1), 381-419. http://dx.doi.org/10.1007/BF00353142.

Citrin, J., \& Luks, S. (2001). Political Trust Revisited: Déja Vu All Over Again? In Theiss-Morse, E., \& Hibbing, J. R. (Eds.), What is It about Government that Americans Dislike?. New York: Cambridge University Press. 
Clarke, H., \& Acock, A. (1989). National Elections and Political Attitudes: The Case of Political Inefficacy. British Journal of Political Science, 19, 551-562. http://dx.doi.org/10.1017/S0007123400005639

Craig, C. (1993). Malevolent Leaders: Popular Discontent in America. Boulder. CO: Westview Press.

DeMaris, A. (1992). Logit Modeling: Practical Applications. Thousand Oaks, CA: Sage Publications. Series: Quantitative Applications in the Social Sciences, No. 106.

Finifter, A. (1970). Dimensions of Political Alienation. American Political Science Review, 65(2), 329-41.

Gamson, W. H. (1968). Power and Discontent. Homewood, IL: Dorsey Press.

Garment, S. (1991). Scandal: The Crisis of Mistrust in American Politics. New York: Random House.

Gilmour, R. S., \& Lamb, R. B. (1975). Political Alienation in Contemporary America. New York: St. Martin's.

Harder, J., \& Krosnick, J. A. (2008). Why Do People Vote? A Psychological Analysis of the Causes of Voter Turnout, Journal of Social Issues, 64(3), 525-549. http://dx.doi.org/10.1111/j.1540-4560.2008.00576.x

Herring, C. (1989). Splitting the Middle: Political Alienation, Acquiescence, and Activism among America's Middle Layers. New York: Praeger.

Hetherington, M. J. (1999). The Effect of Political Trust on the Presidential Vote, 1968-96. American Political Science Review, 93(2), 311-322.

Hetherington, M. J. (1998). The Political Relevance of Political Trust. American Political Science Review, 92(4), 791-808.

Hetherington, M. J. (2005). Why Trust Matters: Declining Political Trust and the Demise of American Liberalism. Princeton, NJ: Princeton University Press.

Hill, D. L. (2006). American Voter Turnout: An Institutional Perspective. Boulder. CO: Westview Press.

Hillygus, D. S. (2005). The Missing Link: Exploring the Relationship between Higher Education and Political Engagement. Political Behavior, 27(1), 25-47. http://dx.doi.org/10.1007/s11109-005-3075-8

Hosmer, D., \& Lemeshow. S. (2000). Applied Logistic Regression (2nd ed). NY: Wiley \& Sons.

Lane, R. (1962). Political Ideology. New York: The Free Press.

Leighley, J. E., \& Nagler, J. (1992). Who Votes?. Journal of Politics, 54, 718-740.

Lyons, W., \& Alexander, R. (2000). A Tale of Two Electorates: Generational Replacement and the Decline of Voting in Presidential Elections. Journal of Politics, 62, 1014-1034. http://dx.doi.org/10.1111/0022-3816.00044.

Nagourney, A. (2008). The '08 Campaign: Sea Change for Politics as We Know It. The New York Times, November 4, 1.

Neuman, F. (1957). The Democratic and the Authoritarian State. New York: The Free Press.

Niemi, R. G., Craig, S. C., \& Mattei, F. (1991). Measuring Internal Political Inefficacy in the 1988 National Election Study. American Political Science Review, 85(4), 1407-1141.

Plutzer, E. (2002). Becoming a Habitual Voter: Inertia, Resources, and Growth in Young Adulthood. American Political Science Review, 96, 41-56. http://dx.doi.org/10.1017/S0003055402004227

Rudolph, T. J., \& Evans, J. (2005). Political Trust, Ideology, and Public Support for Government Spending. American Journal of Political Science, 49(3), 660-671. http://dx.doi.org/10.1111/j.1540-5907.2005.00148.x

Southwell, P. L. (1985). Alienation and Nonvoting in the United States: A Refined Operationalization. Western Political Quarterly, 38(4), 663-674.

Teixeira, R. (1992). The Disappearing Voter. Washington, D.C.: Brookings Institution.

Teixeira, R. (1987). Why Americans Don't Vote: Turnout Decline in the United States 1960-1984. New York: Greenwood Press.

Tenn, S. (2005). An Alternative Measure of Relative Education to Explain Voter Turnout. Journal of Politics. 67(1), 271-282. http://dx.doi.org/10.1111/j.1468-2508.2005.00317.x

Tolchin, S. J. (1989). The Angry American. Boulder, CO: Westview Press.

University of Michigan. (2004). American National Election Study, 2004 Panel Study, ICPSR04293-v1. Ann Arbor, MI: Center for Political Studies. 
Weakliem, D. L., \& Borch, C. (2006). Alienation in the United States: Uniform or Group-Specific Change? Sociological Forum, 21(3), 415-438. http://dx.doi.org/10.1007/s11206-006-9024-4

Weatherford, M. S. (1991). Mapping the Ties that Bind: Legitimacy, Representation, and Alienation. Western Political Quarterly, 44(2), 251-273.

Weatherford, M. S. (1992). Measuring Political Legitimacy. American Political Science Review, 86(1), $149-167$.

Table 1. OLS Regression analysis of dimensions of alienation

\begin{tabular}{|c|c|c|c|c|c|c|}
\hline \multirow[b]{3}{*}{ Variable } & \multicolumn{2}{|c|}{ Model 1} & \multicolumn{2}{|c|}{ Model 2} & \multicolumn{2}{|c|}{ Model 3} \\
\hline & \multicolumn{2}{|c|}{ Internal Efficacy } & \multicolumn{2}{|c|}{ External Efficacy } & \multicolumn{2}{|c|}{ Trust } \\
\hline & Coeff. & $(\mathrm{SE})$ & Coeff. & $(\mathrm{SE})$ & Coeff. & $(\mathrm{SE})$ \\
\hline Education & $.094 * * *$ & $(.019)$ & $.133 * * *$ & $(.017)$ & $.090 * * *$ & $(.013)$ \\
\hline Age & .001 & $(.001)$ & $.003 * * *$ & $(.001)$ & .002 & $(.001)$ \\
\hline Black & $.680 * * *$ & $(.070)$ & $.302 * * *$ & $(.069)$ & .065 & $(.049)$ \\
\hline Latino & $.409 * * *$ & $(.087)$ & $.174^{*}$ & $(.042)$ & .080 & $(.060)$ \\
\hline Other nonwhite race & $.301 *$ & $(.095)$ & .001 & $(.086)$ & .034 & $(.065)$ \\
\hline Female & $.127 * *$ & $(.038)$ & $.126 * * *$ & $(.035)$ & -.048 & $(.026)$ \\
\hline Strength of Partisanship & $.189 * * *$ & $(.023)$ & $.196^{* * *}$ & $(.020)$ & $.099 * * *$ & $(.016)$ \\
\hline Income & .003 & $(.005)$ & .004 & $(.004)$ & .006 & $(.003)$ \\
\hline Constant & $-4.214 * * *$ & $(.112)$ & $-4.509 * * *$ & $(.101)$ & $-4.138 * * *$ & $(.077)$ \\
\hline Observations & \multicolumn{2}{|c|}{2,653} & \multicolumn{2}{|c|}{2,654} & \multicolumn{2}{|c|}{2,653} \\
\hline $\mathrm{R}^{2}$ & \multicolumn{2}{|c|}{.087} & \multicolumn{2}{|c|}{.081} & \multicolumn{2}{|c|}{.046} \\
\hline
\end{tabular}

$* * * \mathrm{p}<.001 ; * * \mathrm{p}<.01 ; * \mathrm{p}<.05$

Source: American National Election Study, 2008-2009, Wave 11 
Table 2. Binary logistic analysis of voter turnout and presidential vote, 2008

\begin{tabular}{|c|c|c|c|c|}
\hline \multirow[b]{3}{*}{ Variable } & \multicolumn{2}{|c|}{ Model 1} & \multicolumn{2}{|c|}{ Model 2} \\
\hline & \multicolumn{2}{|c|}{ Voter Turnout } & \multicolumn{2}{|c|}{ Vote for Obama } \\
\hline & Coeff. & (SE) & Coeff. & (SE) \\
\hline Education & $.447 * * *$ & $(.075)$ & $.281 * * *$ & $(.047)$ \\
\hline Age & $.050 * * *$ & $(.005)$ & -.004 & $(.003)$ \\
\hline Black & .216 & $(.296)$ & $3.840 * * *$ & $(.512)$ \\
\hline Latino & -.080 & $(.299)$ & $.796^{* * *}$ & $(.220)$ \\
\hline Other nonwhite race & -.552 & $(.304)$ & $.619 * *$ & $(.243)$ \\
\hline Female & .068 & $(.146)$ & $.289 * *$ & $(.002)$ \\
\hline Strength of Partisanship & $.640^{* * *}$ & $(.089)$ & $-.168 * *$ & $(.056)$ \\
\hline Income & $.081 * * *$ & $(.017)$ & $-.047 * * *$ & $(.012)$ \\
\hline Internal Efficacy & $.368 * * *$ & $(.099)$ & $.115^{*}$ & $(.051)$ \\
\hline External Efficacy & .136 & $(.113)$ & $.422 * * *$ & $(.074)$ \\
\hline Trust & .130 & $(.134)$ & -.035 & $(.084)$ \\
\hline Constant & $-1.533 * *$ & $(.613)$ & $-4.214 * * *$ & $(.112)$ \\
\hline Observations & \multicolumn{2}{|c|}{2,655} & \multicolumn{2}{|c|}{2,304} \\
\hline Cox \& Snell R Square & \multicolumn{2}{|c|}{.131} & \multicolumn{2}{|c|}{.157} \\
\hline Nagelkerke R Square & \multicolumn{2}{|c|}{.271} & \multicolumn{2}{|c|}{.210} \\
\hline Correctly Predicted & \multicolumn{2}{|c|}{$90.4 \%$} & \multicolumn{2}{|c|}{$65.2 \%$} \\
\hline
\end{tabular}

$* * * \mathrm{p}<.001 ; * * \mathrm{p}<.01 ; * \mathrm{p}<.05$

Source: American National Election Study, 2008-2009, Wave 11

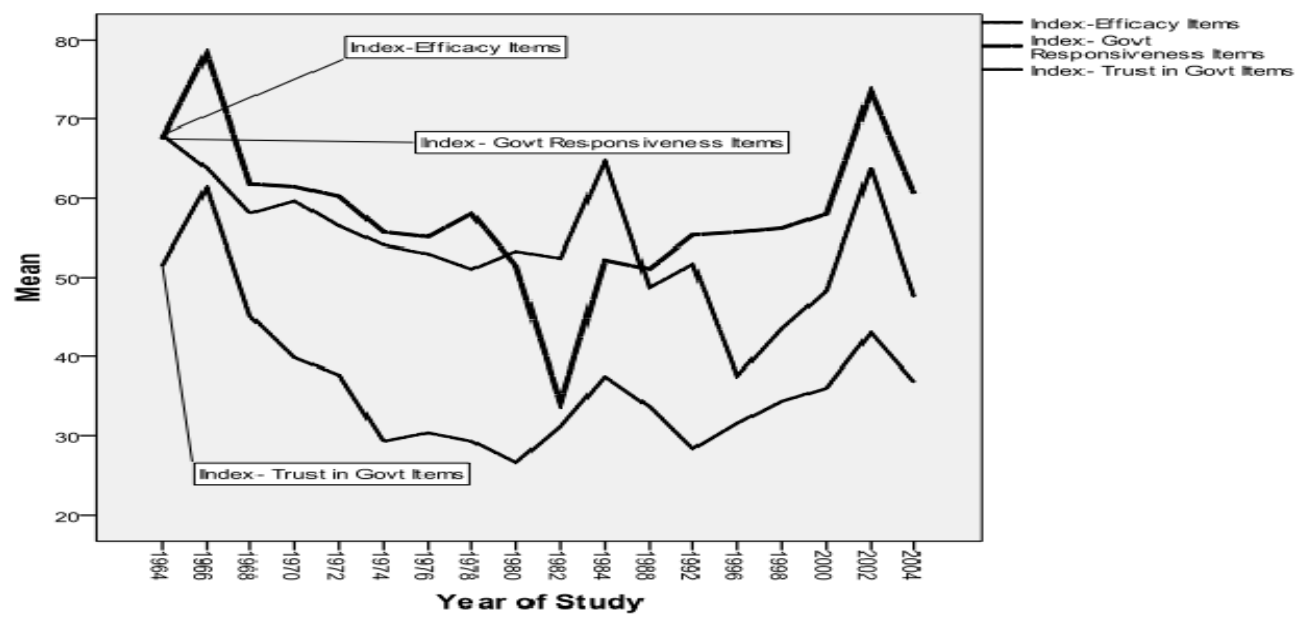

Figure 1. Trends in alienation measures from the American National Election Studies 1964-2004 Source: University of Michigan, Center for Political Studies, American National Election Panel Study, 2004. 


\section{Notes}

Note 1. The University of Michigan's Survey Research Center has included several measures of these three dimensions in its American National Election Study surveys since 1964, as presented in Figure 1 above. Typically four-to-five variables were used to operationalize each dimension of alienation. However, beginning with the 2008 ANES, only one variable is used to measure each of these dimensions. A complete description of these measures in presented in the Appendix.

Note 2. Dummy variables were created for gender and race, excluding the variables for whites and males.

Note 3. In certain electoral contexts, many alienated individuals are provided with an outlet for their frustration at the political system. Specifically, such individuals can and do protest the current state of political affairs by voting for a third party presidential candidate (Atkeson et al. 1996; Hetherington, 1999).

Note 4. Because this data analysis involves dichotomous dependent variables (Voted / Did Not Vote (Model 1) or Voted for Obama / Did Not Vote for Obama (Model 2), certain OLS assumptions are violated; therefore binary logistic regression analysis is used to estimate the effect of each of these variables. Logistic regression applies maximum likelihood estimation after transforming the dependent into a logit variable (the natural log of the odds of the dependent occurring or not). In this way, logistic regression estimates the odds of a certain event occurring. (See DeMaris, 1992; Hosmer \& Lemshow, 2000). The following equation was estimated:

$\mathrm{z}=\mathrm{b} 0+\mathrm{b} 1 \mathrm{X} 1+\mathrm{b} 2 \mathrm{X} 2+$ $+\mathrm{bkXk}$

where $\mathrm{z}$ is the $\log$ odds of the dependent variable and

where $b_{0}$ is the constant and

where there are $\mathrm{k}$ independent $(\mathrm{X})$ variables

Note 5. See Abramson \& Aldrich (1982); Harder \& Krosnick (2008); Hill, (2006); Hillygus (2005); Leighley \& Nagler (2007); Lyons \& Alexander (2000); Plutzer, (2002); Tenn (2007).

\section{Appendix}

\section{Internal Efficacy}

"How much can people like you affect what the government does?" (A great deal, a lot, a

moderate amount, a little, or not at all)

External Efficacy

"How much do government officials care what people like you think?" (A great deal, a lot, a moderate amount, a little, or not at all)

Trust

"How often does the federal government do what most Americans want it to do?" (Always, most of the time, about half the time, once in a while, or never) 